\title{
Resistance to Institutional Change through Decoupling
}

\author{
Jamaliah Abdul Majid \\ Noriah Che Adam
}

\section{Doi:10.5901/mjss.2015.v6n4p531}

\section{Abstract}

This study aims to understand how organisation cope with institutional pressures caused by the implementation of IFRS 3 Business Combinations. Applying an institutional theory, this study proposes that companies might resist the implementation of an impairment-only approach to acquired goodwill, as required by the IFRS 3, especially at the early years of the implementation. The resistance is posited to be in the form of decoupling their accounting policy on goodwill impairment from the substantive implementation of the new system. A case study method was employed to describe the types of resistance to institutional change. The findings reveal two different decoupling strategies undertaken by Malaysian listed companies. In both strategies, companies were perpetuating the old system of amortising their goodwill, which was prohibited by the IFRS 3. However, to resist the institutional pressures of implementing the impairment-only approach to acquired goodwill, the old system was disguised as a new goodwill impairment system. The decoupling strategies highlighted is hoped to help relevant regulatory bodies to take note of impairment test of goodwill conducted by companies, and hence to ensure the true and fair value of goodwill reported on the financial statement.

Keywords: Organisational change; Decoupling; Goodwill impairment; IFRS implementation

\section{Introduction}

The implementation of International Financial Reporting Standards (IFRS) has received supports from worldwide regulatory bodies, such as the International Organization of Securities Commissions (IOSCO), the Committee of European Securities Regulators (CESR), and the World Bank (Jermakowicz and Gornik-Tomaszewsk, 2006; Ding et al, 2007). With such supports, to date, more than 100 countries require or permit the use of IFRS in their financial reporting system (Barth, 2008; Daske et al., 2013). In line with this implementation, there is a growing literature which examines costs and benefits of adopting the IFRS (e.g., Jermakowicz and Gornik-Tomaszewski, 2006; Tyrrall et al, 2007; Ramanna and Sletten, 2014) as well as consequences of the IFRS adoption (e.g., Ahmed et al., 2013; Daske et al., 2013; Hong et al., 2014).

With the supports from the dominant external institutions also, organisations might be pressured to adopt IFRS. Jermakowicz and Gornik-Tomaszewsk, (2006), for example, find that the majority of the European listed companies they interviewed would not adopt IFRS if they were not required by the CESR. Likewise, latridis and Rouvolis (2010) report that the implementation of IFRS has caused volatility in the income statement and balance sheet items of Greek firms. As a result, there is a concerned that some organisations might adopt the IFRS in name only (Daske et al., 2013).

Although the literature on IFRS is growing, one area of investigation which receives little attention is how companies coped with institutional pressures for change, caused by the IFRS adoption. The present study, therefore, aims to address this gap in the literature. Using an institutional theory, this study attempts to understand how organisations cope with institutional pressures caused by the implementation of IFRS 3 . Focusing on an accounting for goodwill impairment required by IFRS 3 and taking listed companies in Malaysia as a case study, the exploration is conducted through semi-structured interviews and detailed analyses of annual reports of two Malaysian listed companies throughout several years, both before and after the implementation of the IFRS 3. Malaysia provides a unique setting because of its unregulated environment on an accounting for goodwill prior to the implementation of the IFRS 3 (Pillai, 2006).

The rationale for focusing on IFRS 3 related to goodwill impairment and its consequential accounting standard, IAS 36 Impairment of Assets, is that these standards afforded managers with discretion in performing an impairment test of goodwill. For example, Ramanna and Watts (2012) argue that the approach of relying exclusively on an impairment review of goodwill represents a major innovation in the accounting treatment for goodwill as it relies purely on the management judgement and estimation. 


\section{Literature Review}

Institutional theory explains decoupling as a form of resistance to change undertaken by organisations, which was caused by pressures from dominant external institution (Pitsakis et al., 2012). Through decoupling, an organisation develops visible symbolic compliance policies or programs that address the institutional pressures but do not implement them substantively in real practices (MacLean \& Behnam, 2010). The symbolic compliance programs could come in various forms, ranging from a complete non-implementation of the programs to subtle forms of decoupling (Westphal and Zajac, 2001). The later could occur when programs or policies are available but disconnected from on-going organisational functions (MacLean \& Behnam, 2010).

Organisations normally resist to institutional pressure for change by decoupling their policies from actual implementation when the external pressure conflicted with their internal targets (Westphal and Zajac, 2001). Reasons for decoupling include safeguarding companies' internal routines from external uncertainties while at the same time gaining legitimacy with external requirements (Westphal and Zajac, 2001). Prior studies demonstrate how organisations developed formal programs such as stock-repurchase programs, total quality management program, or long-term incentive programs without implementing them substantively in real practice, yet these programs help the organisations maintained or gained legitimacy from external institutions (MacLean \& Behnam, 2010). Westphal and Zajac (2001) illustrate how companies initiated a stock repurchase programs due to pressure for accountability without implementing these programs in real practices.

\section{Regulatory Change: IFRS 3 Implementation}

IFRS 3 Business Combinations is the result of a joint effort between the International Accounting Standards Board (IASB) and the United States of America (US) Financial Accounting Standards Board (FASB) to improve financial reporting and promote an international convergence of accounting standards (IASB, 2010a). As Malaysia has a convergence policy with IFRS, its listed companies are required to fully comply with the IFRS 3 in their accounting treatment for goodwill. Nevertheless, in Malaysia, the effective dates for IFRS were January 1, 2006 (MASB, Undated), a year later than the effective dates for the European listed companies.

Prior to the implementation of IFRS 3, Malaysian listed companies do not have a specific accounting standard on goodwill. This unregulated environment has resulted in various accounting treatments for goodwill including capitalisation and amortisation of goodwill, treating goodwill as a permanent item, and an impairment review of goodwill whenever there is an indication (Abdullah et al., 2004). Thus, the implementation of IFRS 3 in 2006 provided listed companies in Malaysia with a specific accounting standard on goodwill, previously unavailable prior to 2006 (Pillai, 2006).

Two main regulatory changes imposed through the implementation of IFRS 3 are the prohibition of an amortisation of goodwill, and the requirement for companies to perform an impairment review of goodwill at least annually (IASB, 2006b). The purpose of the impairment review is to ensure that the carrying amount of the goodwill reported on the balance sheet does not exceeds its recoverable amount (IASB, 2006a; Ernst and Young, 2008). If the recoverable amount of cash-generating-units (CGU) containing goodwill is lower than the carrying amount of the unit, IFRS 3 requires company to report an impairment loss of goodwill.

\section{Research Method}

As the objective of this study is to understand how organisations cope with institutional pressures caused by the implementation of IFRS 3, a case study method is employed. Abdul Majid and Sulaiman (2008) explain that the strength in using case study is that the issue is examined in detailed and in real-world situations. This study is conducted in two stages. In the first stage, we collected data through semi-structured interviews with four group of respondents, namely, a finance manager, a senior auditor, a financial analyst, and a former standard-setter. The semi-structured interviews aim to gain an insight perspective on the implementation of the IFRS 3. A list of open ended interview questions was designed and ethical approval to conduct the interviews was obtained. The interviews focused on two key areas companies' reactions to IFRS 3 implementation, and procedures involved in performing an impairment test of goodwill. All the interviews were tape-recorded and transcribed almost verbatim.

Based on the findings of the semi-structured interviews, in the second stage, we conducted in-depth analyses of goodwill movement of two Malaysian listed companies - SL Limited, and RB Limited. In the in-depth analyses, we focus on four key items that have been discussed by the IAS 36 and prior studies (MASB, 2006, AbuGhazaleh et al., 2011, Abdul Majid, 2013). Figure 1 presented the four key items. To perform the detailed analysis, we refer to companies' 
annual reports, financial data from Datastream, and publicly available data. We then trace the goodwill impairment losses reported from the write-off year back to the acquisition year (i.e., the year the goodwill was acquired).

Figure 1. Four key items employed in analysing signs of decoupling

(1) Ratio of the market capitalisation to the carrying amount of the net assets of the company

(2) Financial performance of the company - i.e. net income pre-goodwill write-off available to equity holders, and basic

earnings per share (EPS)

(3) Financial performance of the cash-generating-units containing the goodwill

(4) Movement of goodwill

Source: Abdul Majid (2013)

\section{Findings and Discussion}

As noted in the previous section, the findings of the semi-structured interviews assist this study in identifying cases of decoupling. Thus, in this section, we present two cases of companies resisting to change by continuing with the old system of amortising their goodwill although the method was prohibited by the IFRS 3 and IAS 36. These are SL Limited and RB Limited ${ }^{1}$.

\subsection{SL Limited}

\subsubsection{Company background}

SL Limited was incorporated in 1982 and it was converted to a public listed company in 1993. In 1994, its shares were listed on the main board of the Bursa Malaysia stock exchange. The company involves primarily in trading of gasoline products throughout Malaysia.

\subsubsection{Accounting policy related to goodwill impairment}

In 2003, the company acquired several service stations, which led to an existence of goodwill on acquisition. Prior to the implementation of IFRS 3, the accounting policy on goodwill of SL Limited was to amortise its goodwill using a straight line method. Thus, under this accounting policy, the goodwill balance of SL Limited was reduced systematically, annually.

As noted earlier, IFRS 3 prohibits an amortisation of goodwill and instead requires companies to perform an impairment review of goodwill, at least annually. When SL Limited implemented IFRS 3 in 2006/7, the company disclosed in its Notes to the financial statement that it is complying with the requirements stipulated by the IFRS, as follows:

With the adoption of (I)FRS 3 beginning 1 April 2006, goodwill represents the excess of the cost of the acquisition over the company's interest in the net fair value of the identifiable assets, liabilities and contingent liabilities of the acquiree. Goodwill is measured at cost and is no longer amortised but tested for impairment at least annually or more frequently when there is objective evidence of impairment. Goodwill is allocated to cash-generating-units.

(SL Limited, 2007)

From 2007 to 2009, the company reported goodwill impairment losses, which reduced its operating profit and net income. Nevertheless, reasons or 'objective evidence' for taking the impairment losses were not disclosed in the annual reports.

\subsubsection{Signs of decoupling}

We examine signs of decoupling by focusing on the four key items, as presented in Figure 1. The next Figure 2 presents the first two key items.

1 In this paper, names of the two companies are anonymised because of the critical comments made about it, which could be priced sensitive if quoted out of context of the study. 


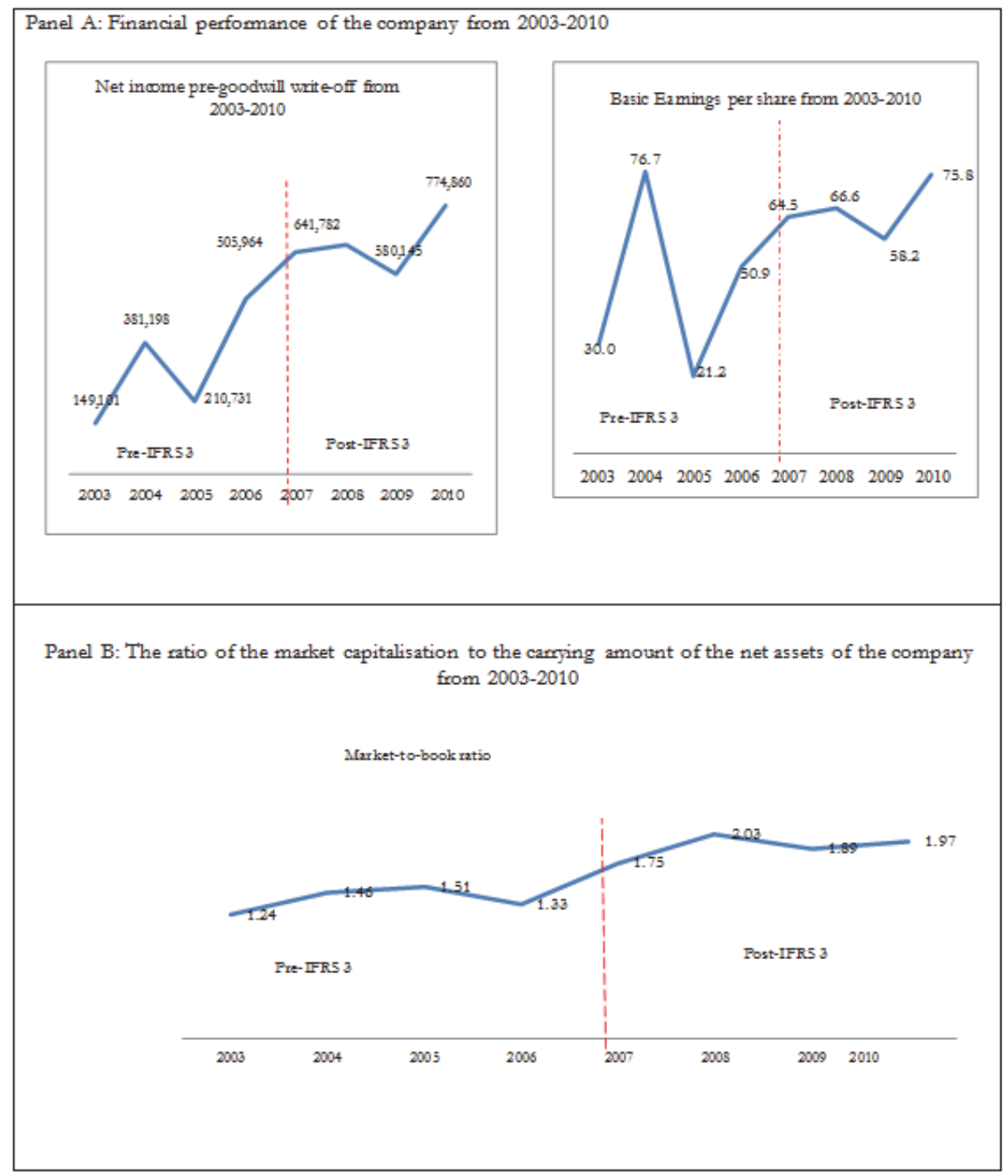

Figure 2. Detailed Analysis of the Financial Performance and the Market-to-book Ratio of SL Limited

Panel A of Figure 2 shows that starting from the year of the acquisition of goodwill in 2003 until 2010, the company portrayed strong financial performances (apart from 2005). This is reflected in the high net income pre-goodwill write-off and the basic earnings per share (EPS). Further, panel B portrayed that the market values of the company remained high above its book values of the net assets, suggesting that investors perceived the company to have more value than the equity reported on its balance sheet. Thus, from Figure 2, it is seen that there is no reason for the company to report goodwill impairment losses after the implementation of IFRS 3, especially from 2007 to 2009, as the company was experiencing good financial performances and strong market capitalisations.

As for the financial performance of the cash-generating-units containing goodwill, no information is disclosed by the company. In the Notes to the financial statement, the company merely disclosed the movement of goodwill within the financial year and its comparison with the previous year. Information concerning the allocation of goodwill to cashgenerating-units, the impairment test conducted, and reasons for reporting the impairment losses from 2007 to 2010 is not disclosed. The lack of detailed disclosure seems to suggest signs of decoupling of the accounting policy on goodwill impairment from the actual impairment test.

Next, we examined the movement of goodwill balance from 2003 to 2010. Table 1 shows that the amount of goodwill impairment losses reported by the company is similar to the amount of goodwill amortisation previously reported, particularly from 2005 to 2009 . With the strong financial performance and the market capitalisation, there is no reason for the company to report goodwill impairment losses. By observing the Notes to the financial statement within a single 
period or for a few periods, company's resistance to change by perpetuating the old system would not be obvious. However, when a comparative analysis was undertaken from the date the goodwill was acquired to the date the impairment loss was reported, it is apparent from Table 1 that the company is continuing the process of reducing its goodwill balance systematically. Instead of recording the amount as goodwill amortisation (see item c), which was prohibited by the IFRS 3, it was disguised as goodwill impairment loss (see item d). Hence, in this case, the company decoupled its accounting policy on an impairment review of goodwill from the actual implementation of the impairment review of goodwill.

Table 1. Analysis of Goodwill Movement for SL Limited from 31 March 2003-2010

\begin{tabular}{|c|c|c|c|c|c|c|c|}
\hline & \multicolumn{4}{|c|}{ Pre-FRS 3 (RM'000) } & \multicolumn{3}{|c|}{ Post-FRS 3 (RM'000) } \\
\hline & 2003 & 2004 & 2005 & 2006 & 2007 & 2008 & 2009 \\
\hline (a) Opening goodwill balance & - & \multicolumn{3}{|c|}{21,902 29,297 27,823 } & 26,349 & 24,874 & 23,400 \\
\hline (b) Additions & 22,166 & 8,536 & - & - & - & - & - \\
\hline (c) Goodwill amortisation & (264) & $(1,141)$ & $(1,474)$ & $(1,474)$ & - & - & - \\
\hline (d) Goodwill impairment & - & - & - & - & $(1,475)$ & $(1,474)$ & $(1,474)$ \\
\hline (e) Closing goodwill balance & 21,902 & 29,297 & 27,823 & 26,349 & 24,874 & 23,400 & 21,926 \\
\hline (f) Goodwill accounting policy & $\begin{array}{r}\text { Goodwill is a } \\
\text { in }\end{array}$ & $\begin{array}{l}\text { rtised frc } \\
\text { recogni }\end{array}$ & $\begin{array}{l}\text { the the } \\
\text { tion }\end{array}$ & late of & Goodwill is & $\begin{array}{l}\text { for impair } \\
\text { frequentl }\end{array}$ & ally or more \\
\hline
\end{tabular}

\subsection{RB Limited}

\subsubsection{Company background}

RB Limited was incorporated in 2003 and it shares were offered to the public in 2004. The company's shares are listed on the second board of the Bursa Malaysia. RB Limited primarily involves in the marketing and distributing of software products.

\subsubsection{Accounting policy related to goodwill impairment}

In 2004, the company acquired $100 \%$ equity interest in another company which led to an exisence of goodwill on acquisition. Prior to the implementation of IFRS 3, the accounting policy on goodwill of RB Limited was to amortise its goodwill over a period of 25 years. Thus, under this accounting policy, the goodwill balance of RB Limited was reduced systematically from year to year.

RB Limited implemented IFRS 3 in 2006 and disclosed in its Notes to the financial statement that the company is complying with the requirements stipulated by the IFRS, as follows:

The adoption of (I)FRS 3 and the revised FRS 136 [similar to IAS 36] has resulted in the Group ceasing annual goodwill amortisation. Goodwill is now carried at cost less accumulated impairment losses and is tested for impairment annually or more frequently if events or changes in circumstances indicate that it might be impaired.

(RB Limited, 2006)

RB Limited reported goodwill impairment losses annually from 2006 to 2008. Unlike SL Limited that did not disclose reasons for the impairment losses reported, RB limited disclosed such reasons in its Notes to the financial statement. However, the reasons disclosed were not only generic in nature but they are also similar from year to year.

\subsubsection{Signs of decoupling}

Figure 3 shows that the financial performances of the company declined from year to year (see panel A) while the the market values of the company remained high above its book values of the net assets from 2004 to 2007 (see panel B). Only, in 2008, the market capitalisation started to decline. Thus, the results for the financial performancces are conflicting with the market capitalisation. We then search for the financial performance of the cash-generating-units (CGUs) containing goodwill. However, no detailed information concerning the financial performance of the CGUs was disclosed by the company. Further, reasons for reporting the impairment losses from 2006 to 2008 were disclosed but were more generic than specific in nature. The lack of detailed disclosure seems to suggest signs of decoupling of the accounting policy on goodwill impairment from the actual impairment review conducted. 


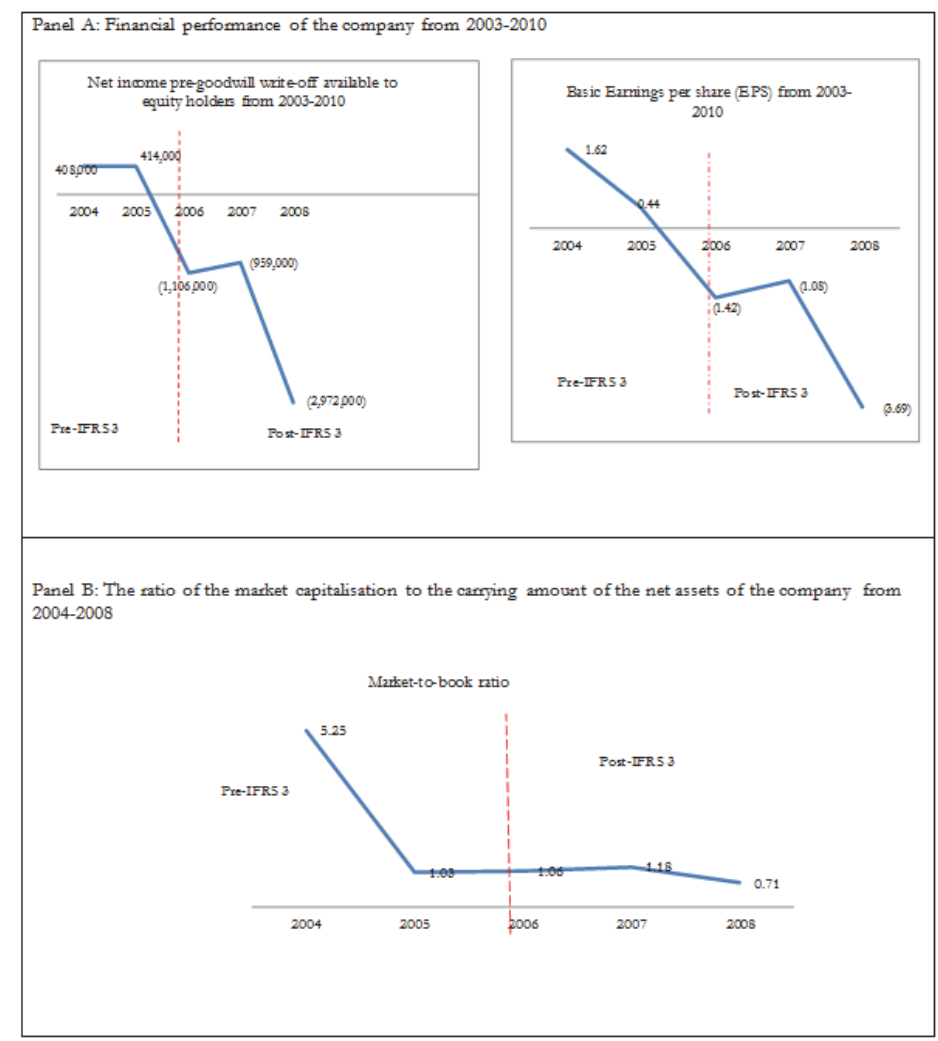

Figure 3. Detailed Analysis of the Financial Performance of the Company and its Market-to-book Ratio for RB Limited

We further explore the signs of decoupling by analysing goodwill movement for RB Limited starting from the date the goodwill existed on acquisition. Based on our detailed analysis, we discovered that unlike SL Limited that reduced its goodwill balance by the same amount annually (i.e. using the straight-line method), RB Limited reduced its goodwill balance with the same percentage in 2006 and 2007 (i.e. using the reducing balance method). Table 2 shows that in 2006 and 2007, the company reduced 10\% of its beginning goodwill balance (see Notes 3 and 4). In 2008, the company's financial performance declined further and its market value fell below the book value of the net assets, which led the company to reduce its beginning goodwill balance by a larger percentage (10\% reduction of goodwill balance for the newly acquired goodwill and $20 \%$ reduction of beginning goodwill balance for the previously acquired goodwill) (see Note 5). The analyses of financial performance presented in Table 2 and goodwill movement portrayed in Figure 2 for RB Limited seems to imply that the managers who were accustomed to the amortisation of goodwill prior to the implementation of IFRS 3 were perpetuating the old system by reporting goodwill impairment losses systematically every year.

Table 2. Analysis of Goodwill Movement for RB Limited from 31 December 2004-2008

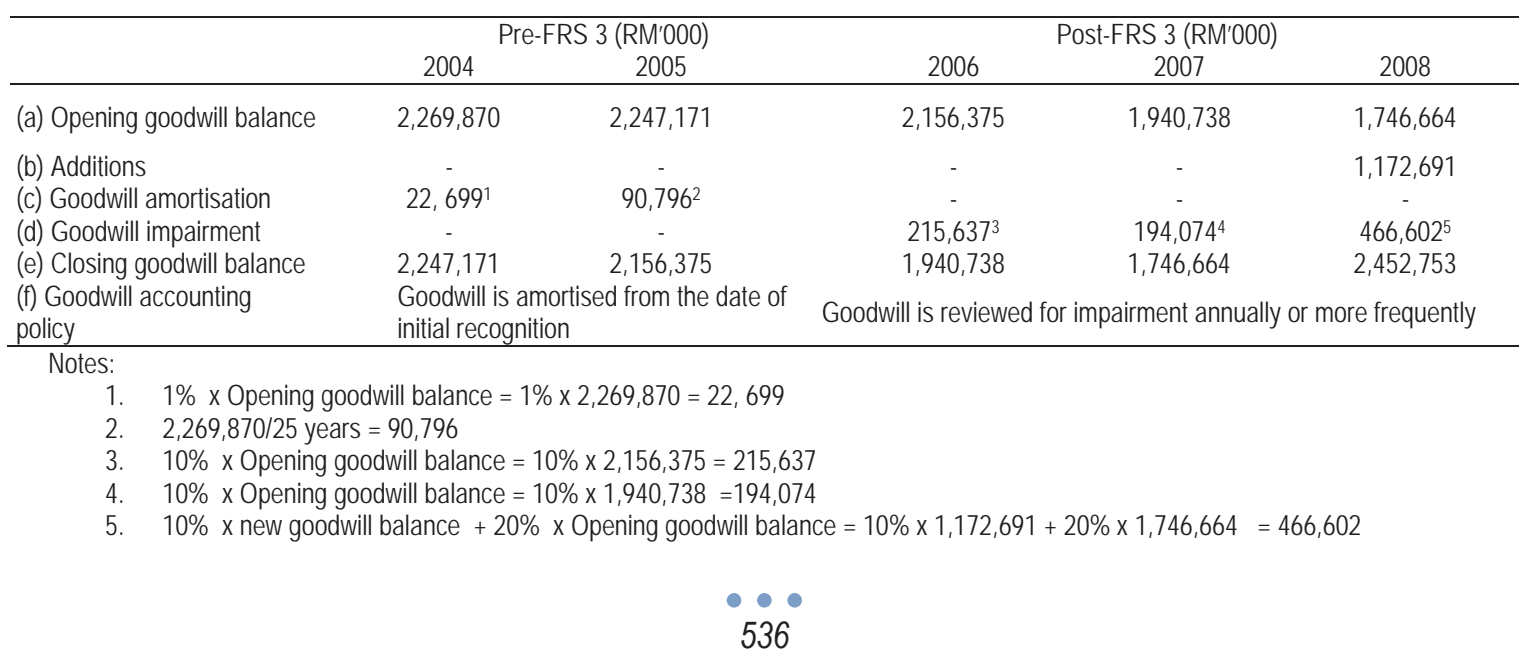


The detailed analyses of financial performances, market capitalisation and goodwill movement for both SL Limited and RB Limited reveal two different decoupling strategies undertaken by these companies in order to resist changing from the old system of goodwill amortisation to the new system of goodwill impairment. The consequence of this resistance to change through decoupling is that companies' earnings on the financial statement are under reported for several years. Further, the resistance to change undertaken by the two companies can be detected by both internal and external auditors through careful analyses of the annual reports, yet the auditors appear not to take any action, as observed in the auditor reports.

\section{Conclusion}

We began by suggesting that one area that has been overlooked by researchers in analysing the implementation of IFRS is how companies coped with institutional pressure for change, caused by the IFRS adoption. Our study has attempted to address this gap. Using an institutional theory, we proposed that companies might resist this institutional pressure, especially at the early years of the implementation. Our study revealed decoupling strategies of perpetuating the old system, disguised as a new impairment system required by the IFRS 3. Further, we demonstrated that the consequence of this decoupling compliance is that earnings were under reported on the financial statements for the past several years, which would hamper the quality of the financial reporting.

The contribution of this study is that it attempts to explain the IFRS implementation from an institutional theory, a theoretical framework that has not been explored before by prior studies. In doing so, the study contributes to the literature by identifying ways in which companies may appear to adopt IFRS 3 related to goodwill impairment but do not apply the IFRS substantively in practise. Hence, the present study provides valuable insights into how organisations coped with institutional pressures for change by decoupling their accounting policy on goodwill impairment from the actual implementation of the impairment review of the goodwill.

While the findings of this study provide insights into how organisations address institutional pressures caused by the implementation of IFRS 3 through decoupling, they do not explain factors influencing this decoupling. Future studies could expand on this study by investigating, on a large scale, motives for this decoupling of the goodwill accounting policy.

\section{Acknowledgements}

We thank the anonymous referee for the constructive suggestions. Financial support from the Ministry of Education of Malaysia via the RACE research grant is gratefully acknowledged.

\section{References}

Abdullah, S. N., Junaidah, H. A., \& Ishak, R. (2004). Accounting treatment for goodwill among Bursa Malaysia main board companies: The case of MAS 6. Malaysian Accounting Review, 3(1), 103-122.

Abdul Majid, J. (2013). Accounting choices relating to goodwill impairment: Evidence from Malaysia. Unpublished PhD thesis. Universitiy of Glasgow, Scotland, United Kingdom.

Abdul Majid, J., \& Sulaiman, M. (2008). Implementation of activity based costing in Malaysia. Asian Review of Accounting, 16(1), $39-55$.

AbuGhazaleh, N. M., Al-Hares, O. M., \& Roberts, C. (2011). Accounting discretion in goodwill impairments: UK evidence. Journal of International Financial Management \& Accounting, 22(3), 165-204.

Ahmed, A. S., Neel, M., \& Wang, D. (2013). Does mandatory adoption of IFRS improve accounting quality? Preliminary evidence. Contemporary Accounting Research, 30(4), 1344-1372.

Barth, M. E. (2008). Global financial reporting: Implications for U.S. academics. The Accounting Review, 83(5), 1159-1179.

Daske, H., Hail, L., Leuz, C., \& Verdi, R. (2013). Adopting a label: Heterogeneity in the economic consequences around IAS/IFRS adoptions. Journal of Accounting Research, 51(3), 495-547.

Ding, Y., Hope, O-K., Jeanjean, T., \& Stolowy, H. (2007). Differences between domestic accounting standards and IAS: Measurement, determinants and implications. Journal of Accounting and Public Policy, 26, 1-38.

Ernst \& Young. (2008). Impairment of fixed assets and goodwill. In International GAAP 2008. Generally Accepted Accounting Practice under International Financial Reporting Standards. United Kingdom: John Wiley \& Sons Inc, 1033-1108.

Hong, H. A., Hung, M., \& Lobo, G. J. (2014). The impact of mandatory IFRS adoption on IPOs in global capital markets. The Accounting Review, 89(4), 1365-1397.

latridis, G., \& Rouvolis, S. (2010). The post-adoption effects of the implementationof International Financial Reporting Standards in Greece. Journal of International Accounting, Auditing and taxation, 19(1), 55-65.

IASB. (2006a). IAS 36 Impairment of Assets. In International Financial Reporting Standards as at 1 January 2006. International 
Accounting Standards Board (IASB), London: IASCF Publications Department.

IASB. (2006b). IFRS 3 Business Combinations. In International Financial Reporting Standards as at 1 January 2006. International Accounting Standards Board (IASB), London: IASCF Publications Department, 273-394.

IASB. (2010a). IFRS 3 Business Combinations. In International Financial Reporting Standards. Official pronouncements issued at 1 January 2010. International Accounting Standards Board (IASB), London: IASC Foundation Publications Department, A93-A139

IASB. (2010b). IAS 36 Impairment of Assets. In International Financial Reporting Standards. Official pronouncements issued at 1 January 2010. International Accounting Standards Board (IASB), London: IASC Foundation Publications Department, A753A801.

Jermakowicz, E. K., \& Gornik-Tomaszewski, S. (2006). Implementing IFRS from the perspective of EU publicly traded companies. Journal of International Accounting, Auditing and Taxation, 15, 170-196.

MacLean, T. L., \& Behnam, M. (2010). The dangers of decoupling: The relationship between compliance programs, legitimacy perceptions, and institutionalised misconduct. Academy of Management Journal, 53(6), 1499-1520.

MASB. (2006). FRS 136 Impairment of Assets. Reporting Foundation and Malaysian Accounting Standards Board (MASB). Kuala Lumpur.

MASB. (Undated). Foreword to Financial Reporting Standards. Available from: <http://www.masb.org.my/index.php?option=com_ content\&view=article\&id=146\%3Aforeword-full-pg2\&catid=9\%3Aforeword\&ltemid=23>. [7 April, 2011].

Pillai, T.S. (2006). Accounting standards for goodwill. Available from: <http://www.pwc.com/en_MY/my/assets/.../pwc_frsgoodwill.pdf_[15 February 2008].

Pitsakis, K., Biniari, M.G., \& Kuin, T. (2012). Resisting change: organizational decoupling through an identity construction perspective. Journal of Organizational Change Management, 25(6), 835-852.

Ramanna, K., \& Sletten, E. (2014). Network effects in countries' adoption of IFRS'. The Accounting Review, 89(4), 1517-1543.

Ramanna, K., \& Watts, R.L. (2012). Evidence on the use of unverifiable estimates in required goodwill impairment. Review of Accounting Studies, 17, 749-780. DOI 10.1007/S11142-012-91885.

Tyrrall, D., Woodward, D., \& Rakhimbekova, A. (2007). The relevance of Internationa Financial Reporting Standards to a developing country: Evidence from Kazakhstan. The International Journal of Accounting, 42, 82-110.

Westphal, J.D., \& Zajac, E.T. (2001). Decoupling policy from practice: The case of stock repurchase programs. Administrative Science Quarterly, 46(2), 202-228. 